\title{
The impact of benthic algae on the settlement of a reef-building coral
}

\author{
G. Diaz-Pulido ${ }^{1 *}$, S. Harii ${ }^{2,3}$, L. J. McCook ${ }^{4}$ and O. Hoegh-Guldberg ${ }^{1}$ \\ ${ }^{1}$ Centre for Marine Studies and Australian Research Council Centre of Excellence for Coral \\ Reef Studies, The University of Queensland, St Lucia, Brisbane, Queensland 4072, Australia \\ ${ }^{2}$ Centre for Marine Studies, The University of Queensland, St Lucia, Brisbane, Queensland \\ 4072, Australia. \\ ${ }^{3}$ Current address: Graduate School of Engineering and Science, University of the Ryukyus \\ Nishihara, Okinawa 903-0213, Japan \\ ${ }^{4}$ Great Barrier Reef Marine Park Authority, PO Box 1379, Townsville, Queensland, \\ Australia, and Pew Fellowships Program in Marine Conservation \\ *Corresponding author. Email address: g.diazpulido@uq.edu.au; Telephone: +61-7- \\ 33653378; Fax: +61-7-33654755
}

Keywords: macroalgae, coral reefs, coral larvae, reef degradation, reef resilience 


\begin{abstract}
The capacity of corals to re-establish in degraded and algal-dominated habitats will depend on the effects of algae on coral settlement and growth. We tested the effect of 11 macroalgal species, of widely different functional-forms, on swimming and settlement by larvae of the coral Platygyra daedalea from the Great Barrier Reef. Algal turfs and the crustose calcareous algae groups had minor effects on coral settlement, while upright calcareous and fleshy macroalgae inhibited settlement. However, the extent of inhibition of larval settlement differed among upright macroalgal species, variations that were not well explained by physical differences and probably reflect chemical differences not explained by functional-form. Thus, while algal functional-form is useful in identifying general competition patterns, more detailed taxonomic and chemical approaches may be required to fully understand algal effects on corals. Different macroalgal communities on degraded reefs may have different effects on coral settlement, and hence on coral population resilience.
\end{abstract}




\section{Introduction}

Inhibition of coral recruitment by benthic algae is a critical bottleneck in the recovery and resilience of coral reefs, especially under climate change scenarios (Birrell et al. 2008a). Increasingly frequent and severe disturbances, such as mass bleaching, are causing increasing, large-scale coral mortality, usually followed by colonisation and dominance by a range of benthic algae (Hoegh-Guldberg et al. 2007; Diaz-Pulido et al. 2009). Recovery of coral populations therefore depends on the ability of coral larvae to successfully settle and recruit on substrata dominated by benthic algae, or the ability of remnant corals to vegetatively overgrow substrata occupied by benthic algae. Consequently, the nature and composition of the algal community that dominates degraded reefs, and the different effects of those algae on the processes of coral population recovery are likely to be critical to the outcome for the reef (Hughes et al. 2007; Birrell et al. 2008a). Previous studies have shown that different types of algae have very different effects on corals and that the variability in the interactions and effects can be largely explained in terms of the functional-form groups of algae (McCook et al. 2001).

Similarly, differences in algal morphology and chemistry are likely to have important effects on microhabitats for coral recruitment (Birrell et al. 2008a). However, even less is known about the effects of different types of benthic algae on early life history stages of corals (reviewed by Birrell et al. 2008a) than on established corals. In the few examples available, fleshy macroalgae reduced coral settlement, although there is high variability in the outcomes. Most experiments used very few species of fleshy algae (2-5 species; Maypa and Raymundo 2004; Nugues and Szmant 2006; Kuffner et al. 2006; Birrell et al. 2008b) or focussed on the induction of coral settlement by crustose coralline algae (e.g., Harrington et al. 2004; Golbuu and Richmond 2007). Only one study considered effects on the swimming activity of coral larvae (Birrell et al. 2008b). 
In the present study, the individual effects of 11 species of benthic algae, from a range of different functional-form groups, on the swimming activity and settlement of larvae of a common coral species from Heron Island (HI) were examined on the Great Barrier Reef, Australia (GBR). The relationship between variability in larval activity and settlement and the functional-form of the algae was considered in particular, although the study was not intended as a definitive test for differences amongst functional-form groups.

\section{Materials and methods}

\section{General approach and collection of algae}

The swimming activity and settlement of larvae of the broadcast spawning coral Platygyra daedalea were compared on substrates placed adjacent to thalli of 11 species of benthic algae. $P$. daedalea is widely distributed in the Indo Pacific and is common in most reef habitats of the GBR (Nozawa and Harrison 2002). Discs of the crustose coralline alga Porolithon onkodes ( $3 \mathrm{~cm}$ diameter, ca. $1 \mathrm{~cm}$ height) were used as settling substrate. $P$. onkodes has been shown to induce the settlement of a wide variety of coral larvae (Heyward and Negri 1999), and is the most common crustose coralline alga in the area from which corals were collected. Discs were collected using a pneumatic drill fitted with a holesaw. The larval activity and settlement were compared in treatments with P. onkodes alone (control) and with other algae in addition to $P$. onkodes.

To explore how the physical structure of the algae may affect swimming and settlement of coral larvae, green plastic algal mimics $(8 \mathrm{~cm}$ height and roughly resembling Halimeda spp.) obtained from an aquarium shop were used. The plastic algae were soaked for ca. 4 hours in freshwater and rinsed with filtered seawater prior to the experiments. In all, there were 11 algal treatments (including the control with $P$. onkodes), and one plastic mimic, each with 4 replicate containers (total of 48 containers). 
The 11 types of benthic algae used are common on coral reefs and included representatives of most categories and functional-form groups of macroalgae (Table 1; Steneck and Dethier 1994). The algae used include taxa previously reported to either inhibit or induce coral settlement and metamorphosis. Most macroalgae were collected from the reef flat at HI (mean depth of 1-3 m), with the exceptions of Halimeda discoidea and Peyssonnelia sp., collected from $8 \mathrm{~m}$ depth on the reef slope, and P. onkodes which was collected from the shallow reef slope of nearby Wistari reef (although also common on the reef flat at $\mathrm{HI})$. The macroalgae were handled carefully and maintained in aquaria with running seawater in the outdoor facilities at the Heron Island Research Station (HIRS) prior to the experiment.

\section{Collection of coral larvae}

Mature colonies of the coral Platygyra daedalea were collected from the reef flat on HI a few days before the spawning, which occurred on the 13th November 2006. Corals were kept in tanks with running seawater in the outdoor facilities at HIRS until spawning. Eggs and sperm were mixed and fertilised eggs washed twice in filtered seawater (FSW, 0.22 microns), then kept in plastic containers with daily water exchange.

\section{Effects of algae on swimming activity and settlement}

Fifty coral larvae were added to each plastic container with experimental algae two days after spawning. Each of the 48 1.5L containers was filled with FSW, and contained a clump of one of the experimental algae (ca. 0.4 g dry weight (DW) of each of the fleshy forms, $0.7 \mathrm{~g}$ DW of the calcareous alga Halimeda discoidea, $1.6 \mathrm{~g}$ DW of Peyssonnelia sp.), and a disc of $P$. onkodes (ca. $2.5 \mathrm{~g} \mathrm{DW}$ ). For the algal turf treatment, ceramic tiles of $5 \times 5 \mathrm{~cm}$ overgrown by a turf of filamentous algae of ca. $<3 \mathrm{~mm}$ height were used. Tiles were placed on the bottom of the containers $2-3 \mathrm{~cm}$ from the $P$. onkodes discs. Turf tiles were preconditioned 
in the HI reef flat for 5 months prior to the experiment, and were examined for settled coral spat before the experiment. Positive controls included a disc of $P$. onkodes only. Containers were kept in $12 \mathrm{~h}$ light: $12 \mathrm{~h}$ dark conditions in a laboratory at $26^{\circ} \mathrm{C}$ and water replaced daily. Estimates of oxygen consumption due to 12 hours dark respiration suggest that, in containers of this volume, oxygen saturation in the containers remained high $(>80 \%)$.

The number of larvae swimming near the surface of the water (i.e., the top $\mathrm{cm}$ of the water column, hereafter called on the surface), or swimming in the water column, were counted on days 2, 3, 5 and 8 after spawning. The number of larvae settled (i.e., attached and having begun to metamorphose) on the $P$. onkodes discs was scored under a dissecting microscope at day 8 , since available information indicates that $P$. daedalea settlement peaks at that age (Nozawa and Harrison 2002). Larvae settled on the sides or underneath the discs of $P$. onkodes and there was no settlement on the plastic containers. Settlement onto the experimental algal thalli was negligible (only one spat was found on one algal thallus). Data were analysed using one way ANOVAs and Tukey post-hoc multiple comparisons to test for effects on the mean percentage of swimming and settled larvae. Data were not transformed, based on checks for normality, using stem and leaf plots and probability plots; and for homogeneity of variance with Cochran's test.

\section{Results and discussion}

Macroalgae significantly affected the swimming activity and settlement of larvae of the coral Platygyra daedalea. However, the effects varied with the age of the larvae, the algal categories and functional-form groups, and between species within functional-form groups. Swimming activity of 2 day old larvae was significantly different only for two members of the leathery macrophyte group, both species of Sargassum. More larvae were swimming on the surface of the water in the S. muricatum treatment (95\%) than in most of the other algal treatments and the controls (Fig. 1; Table 2). In contrast, only 50\% of larvae were swimming 
on the surface in the $S$. tenerrimum treatment. Macroalgal effects on the swimming activity of 3 day old larvae were less marked and not significantly different amongst algal treatments (Table 2). However, approximately $80 \%$ of the larvae in the $S$. muricatum treatment were on the water surface, compared to only $40 \%$ in the algal turf treatment. By day 5 , the proportion of larvae remaining at the water surface was low $(<13 \%)$ in all algal treatments, and was lower in the algal turf treatment than several other treatments. By day 8 , less than $7 \%$ of the larvae in all treatments remained on the water surface, or swimming in the water column. The remaining larvae had attached and settled, or had died.

Most upright macroalgae strongly reduced the settlement of coral larvae onto discs of P. onkodes ( $p<0.001$; Fig 2 ; Table 2$)$. Larval settlement was significantly lower $(<5 \%)$ in treatments containing most upright fleshy algae (except Hypnea pannosa and Melanamansia glomerulata), articulated calcareous algae (Halimeda discoidea), and the crustose alga Peyssonnelia sp, than in the controls with no fleshy algae added (P. onkodes only; $30 \%$ settlement) and algal turf treatments (25\%). Algal turfs and $P$. onkodes clearly enhanced the settlement of larvae compared to the upright macroalgal treatments. There was, however, also considerable variability in the effects of fleshy macroalgae on coral settlement. For instance, the corticated alga Hypnea pannosa had less effect (11\% settlement) than Laurencia intricata (only $0.5 \%$ ), although both belong to the same functional-form group, corticated macrophytes, and hence share similar morphological and anatomical features. Interestingly, the plastic mimic strongly reduced coral settlement of larvae. Only $3 \%$ of the corals settled in the plastic mimic treatment, compared to ca. $30 \%$ settlement in the control and algal turf treatment.

The results of this study provide the first exploration of the effects on coral settlement behaviour for such a wide range of coral reef algae. In particular, the results show that although the broad algal categories (i.e., algal turfs, upright macroalgae and crustose algae, 
Table 1) can explain some of the major differences in effects, there remain quite large differences among species within functional groups (i.e., the subsets of algal categories, Table 1). Algal turfs and crustose coralline algae enhanced the settlement of the coral larvae, while all upright fleshy and calcareous macroalgae generally inhibited the settlement (Fig. 2). Algal turfs have been generally shown to provide an adequate substrate for coral settlement (reviewed in Birrell et al. 2008a). However, algal turfs vary considerably in species composition, density, height, sediment trapping, and other properties, so that their effects on coral settlement should be assumed to vary considerably (e.g., Birkeland 1977; Birrell et al. 2008a). Among the upright macroalgae, the extent of settlement inhibition varied considerably within functional groups. There were even differences between species within the same genus (Sargassum). Kuffner et al. (2006) found that two species of the foliose algae group reduced the recruitment of the coral Porites astreoides, but noted differences in the strength of inhibition. Interestingly and in contrast to the inhibition seen in our results, Birrell et al. (2008b) observed higher settlement of Acropora millepora larvae in treatments containing chemicals released by L. variegata than in treatments without algae.

The inhibition of settlement by upright macroalgae generally is likely due to both physical (shading) and chemical effects, but the differences amongst upright macroalgae, especially taxa with very similar morphologies, seem likely to reflect chemical differences, since similar morphologies presumably have similar physical properties. However, the reduced larval settlement in the presence of the plastic mimics may suggest that the physical structure of upright algae affects settlement of larvae of the coral Platygyra daedalea. It may be that the larvae detect changes in the topographic quality of the surface, avoiding threedimensional structures resembling upright macroalgal thalli. This response could benefit the coral by avoiding shade, reduced flow (i.e., boundary layers) or high sediment regimes, as suggested for other invertebrate larvae (Duggins et al. 1900). 
The two species of the crustose calcareous algae group examined had contrasting effects on settlement, as had been observed before (Baird and Morse 2004; Golbuu and Richmond 2007). These differences may be related to differences in calcification: Coralline algae (i.e., Order Corallinales) such as $P$. onkodes deposit high-magnesium calcite throughout the thalli, whereas the Peyssonnelia sp. (Order Gigartinales) deposits aragonite in the basal layers and does not calcify as solidly, potentially limiting access of settling larvae to a calcareous surface (Littler and Littler 1984). Thus, although the functional-form group classification provides a useful general framework (Birrell et al. 2008a), the substantial variability observed both in this study and the literature suggests that a more detailed chemical and taxonomic approach will be required for a comprehensive understanding of the effects of benthic algae on early life stages of corals.

This study provides important insight into the ecological resilience of coral populations, particularly under climate change scenarios leading to increased coral mortality and algal overgrowth (Hoegh-Guldberg et al. 2007; Diaz-Pulido et al. 2009). Our data provide evidence that the type of algae that dominate will have profound consequences for the replenishment of coral populations on degraded reefs. Recovery of reefs by coral recruitment seems more likely on reefs dominated by algal turfs and crustose calcareous algae (particularly crustose coralline algae) than those with abundant upright fleshy seaweeds. Fleshy macroalgae can reduce the settlement and alter the swimming activity of coral larvae, potentially perpetuating phase shifts (Mumby et al. 2007; Birrell et al. 2008a). The effects of seaweed beds on swimming behaviour of coral larvae may be critical to the long-term persistence of corals on those reefs. Better information on the nature and variations in these effects will be critical to understanding the resilience of coral populations. 


\section{Acknowledgements}

This project was supported by the Australian Research Council Centre of Excellence

for Coral Reef Studies and the PEW Program in Marine Conservation. Thanks to M.

Rodriguez-Lanetty, T. Ridgeway and E. Sampayo for help in the laboratory, and to P.

Mumby and the reviewers for comments on the manuscript.

\section{Reference List}

Baird AH, Morse ANC (2004) Induction of metamorphosis in larvae of the brooding corals Acropora palifera and Stylophora pistillata. Mar Freshw Res 55: 469-472

Birkeland C (1977) The importance of rate of biomass accumulation in early successional stages of benthic communities to the survival of coral recruits. Proc 3rd Int Coral Reef Symp 1: 15-21.

Birrell CL, McCook LJ, Willis BL, Diaz-Pulido G (2008a) Effects of benthic algae on the replenishment of corals and the implications for the resilience of coral reefs. Oceanogr Mar Biol Annu Rev 46: 25-64

Birrell CL, McCook LJ, Willis BL, Harrington L (2008b) Chemical effects of macroalgae on larval settlement of the broadcast spawning coral, Acropora millepora. Mar Ecol Prog Ser 129-137

Diaz-Pulido G, McCook LJ, Dove S, Berkelmans R, Roff J, Kline DI, Weeks S, Evans RD, Williamson DH, Hoegh-Guldberg O (2009) Doom and boom on a resilient reef: Climate change, algal overgrowth and coral recovery. PLoS ONE 'in press'

Duggins DO, Eckman JE, Sewell AT (1900) Ecology of understory kelp environments. II. Effects of kelps on recruitment of benthic invertebrates. J Exp Mar Biol Ecol 143: 21-45

Golbuu Y, Richmond RH (2007) Substratum preferences in planula larvae of two species of scleractinian corals, Goniastrea retiformis and Stylaraea punctata. Mar Biol 152: 639644

Harrington L, Fabricius KE, De'ath G, Negri AP (2004) Recognition and selection of settlement substrata determine post-settlement survival in corals. Ecology 85: 34283437

Heyward AJ, Negri AP (1999) Natural inducers of coral larval metamorphosis. Coral Reefs 18: $273-279$

Hoegh-Guldberg O, Mumby PJ, Hooten AJ, Steneck RS, Greenfield P, Gomez E, Harvell CD, Sale PF, Edwards AJ, Caldeira K, Knowlton N, Eakin CM, Iglesias-Prieto R, Muthiga N, Bradbury RH, Dubi A, Hatziolos ME (2007) Coral reefs under rapid climate change and ocean acidification. Science 318: 1737-1742

Hughes TP, Rodrigues MJ, Bellwood DR, Ceccarelli DM, Hoegh-Guldberg O, McCook LJ, Moltschaniwskyj NA, Pratchett MS, Steneck RS, Willis BL (2007) Phase shifts, herbivory, and the resilience of coral reefs to climate change. Curr Biol 17: 1-6

Kuffner IB, Walters LJ, Becerro MA, Paul VJ, Ritson-Williams R, Beach KS (2006) Inhibition of coral recruitment by macroalgae and cyanobacteria. Mar Ecol Prog Ser 323: $107-117$ 
Littler MM, Littler DS (1984) Models of tropical reef biogenesis: the contribution of algae. Prog Phycol Res 3: 323-364

Maypa AP, Raymundo LJ (2004) Algae-coral interactions: mediation of coral settlement, early survival, and growth by macroalgae. Silliman Journal 45: 76-95

McCook LJ, Jompa J, Diaz-Pulido G (2001) Competition between corals and algae on coral reefs: a review of evidence and mechanisms. Coral Reefs 19: 400-417

Mumby PJ, Harborne AR, Williams J, Kappel CV, Brumbaugh DR, Micheli F, Holmes KE, Dahlgren CP, Paris CB, Blackwell PG (2007) Trophic cascade facilitates coral recruitment in a marine reserve. Proc Natl Acad Sci USA 104: 8362-8367

Nozawa Y, Harrison PL (2002) Larval settlement patterns, dispersal potential, and the effects of temperature on settlement of larvae of the coral, Platygyra daedalea, from the Great Barrier Reef. Proc Ninth Int Coral Reef Symp 1: 409-415

Nugues MM, Szmant AM (2006) Coral settlement onto Halimeda opuntia: a fatal attraction to an ephemeral substrate? Coral Reefs 25: 585-591

Steneck RS, Dethier MN (1994) A functional group approach to the structure of algaldominated communities. Oikos 69: 476-498 


\section{Figure legends}

Figure 1. Percentage of 2 day-old larvae of the coral Platygyra daedalea swimming on the top cm of the water column across macroalgal treatments. Sargassum mur: Sargassum muricatum; Sargassum ten: Sargassum tenerrimum; Poro: Porolithon onkodes. $\mathrm{n}=4 \pm \mathrm{SE}$.

Figure 2. Percentage of settlement of 8 day-old larvae of the coral Platygyra daedalea on crustose coralline alga Porolithon onkodes across macroalgal treatments. Sargassum mur: Sargassum muricatum; Sargassum ten: Sargassum tenerrimum; Poro: Porolithon onkodes. $\mathrm{n}=4 \pm$ SE. 
2 day old larvae

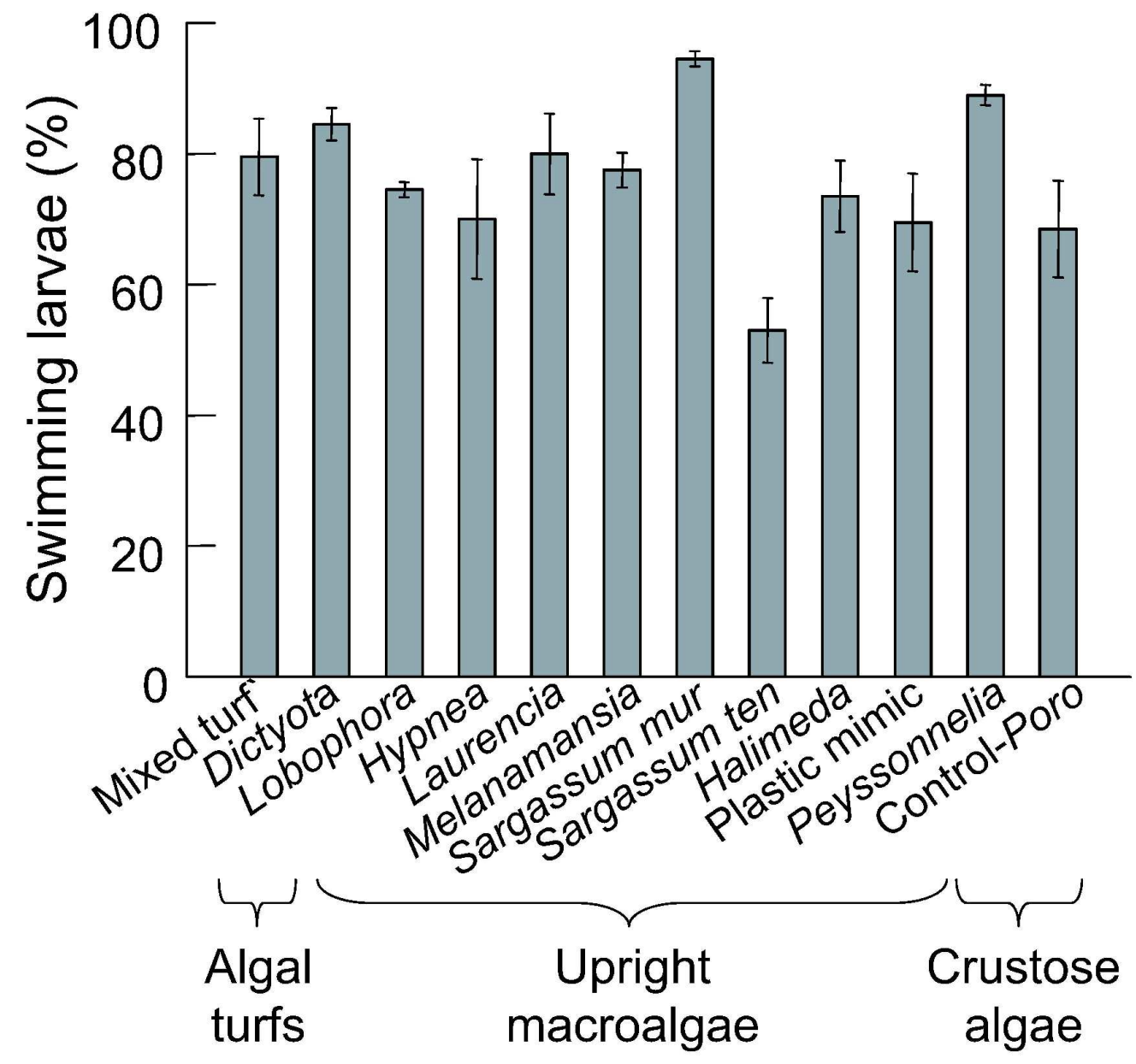

Percentage of 2 day-old larvae of the coral Platygyra daedalea swimming on the top $\mathrm{cm}$ of the water column across macroalgal treatments. Sargassum mur: Sargassum muricatum; Sargassum ten: Sargassum tenerrimum; Poro: Porolithon onkodes. $n=4 \pm S E$. $145 \times 147 \mathrm{~mm}(600 \times 600 \mathrm{DPI})$ 


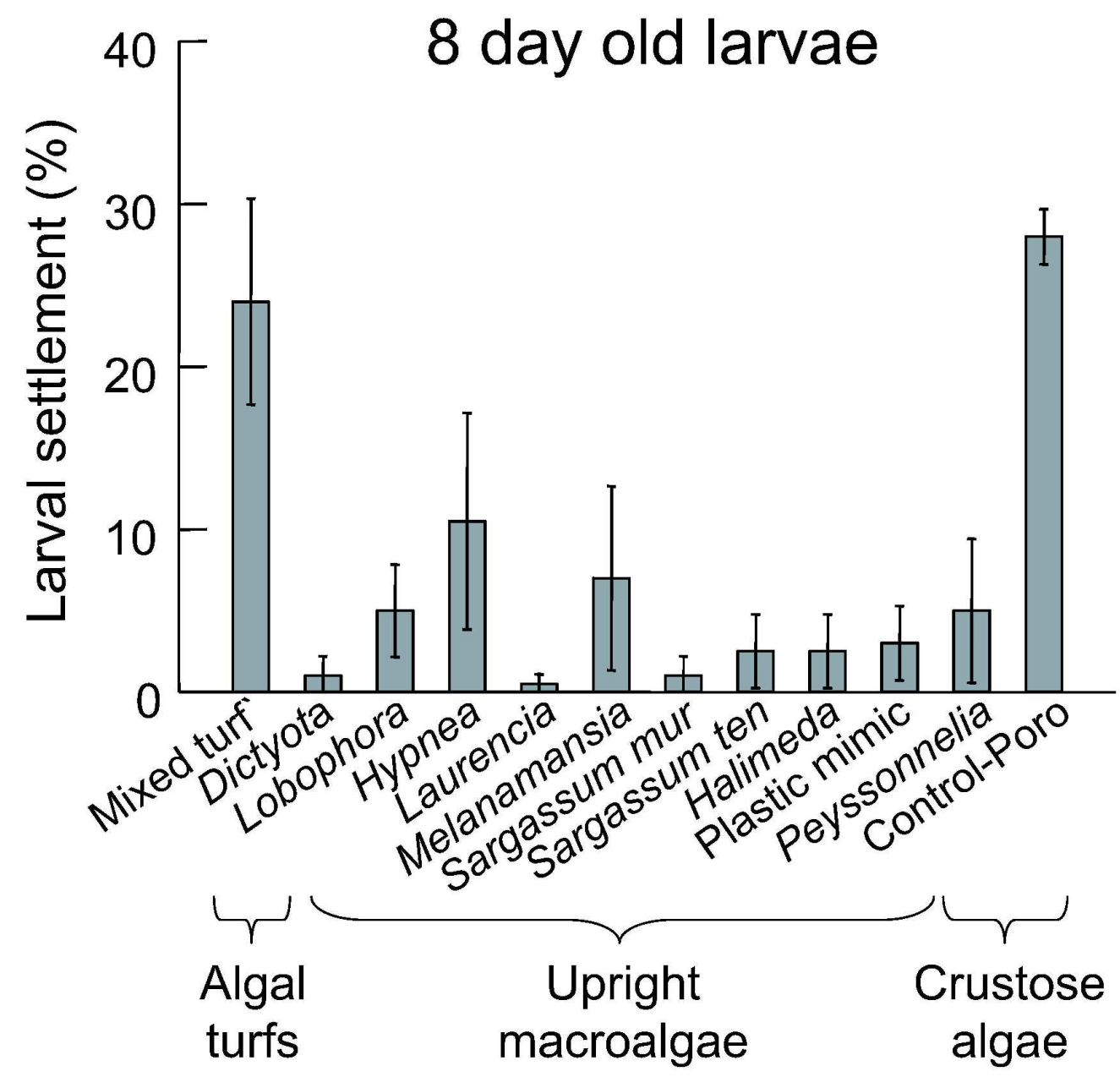

Percentage of settlement of 8 day-old larvae of the coral Platygyra daedalea on crustose coralline alga Porolithon onkodes across macroalgal treatments. Sargassum mur: Sargassum muricatum; Sargassum ten: Sargassum tenerrimum; Poro: Porolithon onkodes. $n=4 \pm S E$. $144 \times 139 \mathrm{~mm}(600 \times 600 \mathrm{DPI})$ 


\section{Tables}

Table 1. Categories and functional form groups of benthic algae used in this study (modified from Steneck and Dethier 1994).

\begin{tabular}{|c|c|c|c|}
\hline \multicolumn{2}{|c|}{ Algal categories } & $\begin{array}{l}\text { Functional } \\
\text { groups }\end{array}$ & Taxa used in this study \\
\hline Algal turfs & & $\begin{array}{l}\text { Filamentous } \\
\text { turfs }\end{array}$ & $\begin{array}{l}\text { Mixed species: Hincksia mitchelliae, } \\
\text { Polysiphonia spp., Sphacelaria spp. }\end{array}$ \\
\hline \multirow[t]{2}{*}{$\begin{array}{l}\text { "Upright" } \\
\text { macroalgae }\end{array}$} & Fleshy & $\begin{array}{l}\text {-Corticated } \\
\text { foliose algae } \\
\text {-Corticated } \\
\text { macrophytes } \\
\text {-Leathery } \\
\text { macrophytes }\end{array}$ & $\begin{array}{l}\text { Dictyota ceylanica, Lobophora variegata } \\
\text { Hypnea pannosa, Laurencia intricata, } \\
\text { Melanamansia glomerulata } \\
\text { Sargassum muricatum, S. tenerrimum }\end{array}$ \\
\hline & Calcareous & $\begin{array}{l}\text {-Articulated } \\
\text { calcareous algae }\end{array}$ & Halimeda discoidea \\
\hline \multicolumn{2}{|c|}{ Crustose calcareous algae } & $\begin{array}{l}\text { Crustose } \\
\text { calcareous algae }\end{array}$ & $\begin{array}{l}\text { Peyssonnelia sp.(heavily calcified), } \\
\text { Porolithon onkodes }\end{array}$ \\
\hline
\end{tabular}


Table 2. One way ANOVAs for the effects of macroalgal species on the \% of larvae of the coral Platygyra dadelea swimming on the top $\mathrm{cm}$ of the water column and settling on discs of the crustose coralline alga Porolithon onkodes in laboratory experiments. MS: Mean square. Sar m: Sargassum muricatum; Por: Porolithon onkodes; Hal: Halimeda discoidea; Hyp: Hypnea pannosa; Pla: Plastic mimic; Sar t: Sargassum tenerrimum; Mel: Melanamansia glomerulata; Dic: Dictyota ceylanica; Lau: Laurencia intricata; Lob: Lobophora variegata; Pey: Peyssonnelia sp.; Tur: Algal turfs; n.s.: not significant.

\begin{tabular}{|c|c|c|c|c|c|}
\hline Source of variation & df & MS & $\mathrm{F}$ & $p$ & Conclusion - Tukey's test \\
\hline \multicolumn{6}{|l|}{$\begin{array}{l}\text { \% Swimming larvae } \\
\text { (2-day old) }\end{array}$} \\
\hline Macroalgae & 11 & 467.52 & 5.93 & $<0.001$ & $\begin{array}{l}\text { Sar } \mathrm{m}>\text { Por=Hal=Hyp=Pla. Sar } \mathrm{t}<\mathrm{Mel}= \\
\text { Dic=Hal=Lau=Lob=Pey=Tur. Sar } \mathrm{t}<\text { Sar } \mathrm{m}\end{array}$ \\
\hline Error & 36 & 78.89 & & & \\
\hline $\begin{array}{l}\text { \% Swimming larvae } \\
\text { (3-day old) }\end{array}$ & & & & & \\
\hline Macroalgae & 11 & 377.06 & 1.48 & 0.182 & n.s. \\
\hline Error & 36 & 254.78 & & & \\
\hline \multicolumn{6}{|l|}{$\begin{array}{l}\text { \% Swimming larvae } \\
\text { (5-day old) }\end{array}$} \\
\hline Macroalgae & 11 & 48.52 & 2.83 & 0.009 & Turf $<$ Lau $=$ Pey $=$ Pla $=$ Sar $\mathrm{m}$ \\
\hline Error & 36 & 17.17 & & & \\
\hline \multicolumn{6}{|l|}{$\begin{array}{l}\text { \% Swimming larvae } \\
\text { (8-day old) }\end{array}$} \\
\hline Macroalgae & 11 & 14.27 & 1.05 & 0.429 & n.s. \\
\hline Error & 36 & 13.64 & & & \\
\hline \multicolumn{6}{|l|}{$\%$ Settlement } \\
\hline Macroalgae & 11 & 333.82 & 8.66 & $<0.001$ & $\begin{array}{l}\text { Por }>\text { all, except: Por }=\text { Turf. Turf }>\text { all, } \\
\text { except: Turf=Por. Turf }=\text { Hyp }\end{array}$ \\
\hline Error & 36 & 38.56 & & & \\
\hline
\end{tabular}

